\title{
イオン交換膜面に析出する炭酸カルシゥム スケール結晶の形状と変態(2)
}

\author{
(1972 年 4 月 8 日 受 理)
}

武本 長 昭*

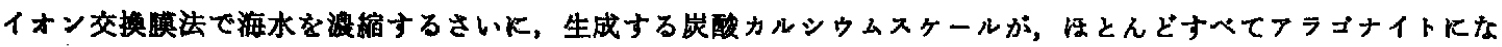

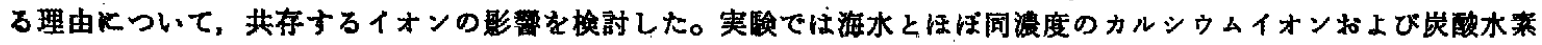
イオンを含を塩化ナトリウム溶液に、マグネシウム，カリウム，硫酸の各イオンをそれぞれ添加して調製した溶液を 原液とし，水分解を生じない程度の過脱塩条件で電気透析洪縮を行ない，生成した能酸カルシウムスケール結晶の形

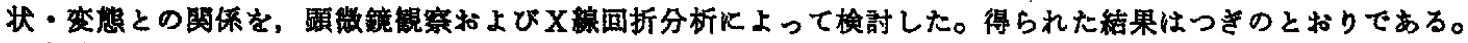

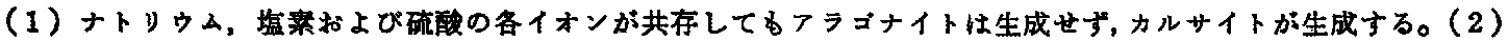

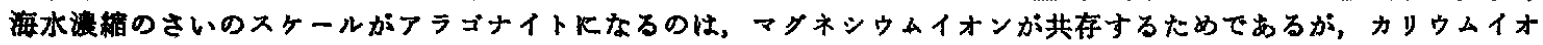
ソの共存によってるフラゴナイトを生ずる。（3）カリウムイオンの共存量とアラジナイトの生成比との間住，析 出速度が小さいときにはほぼ比関係があるが，析出速度が大になるとアラゴナイトの生成がほとんど幄められなく なる。
\end{abstract}

\section{1 腥苇}

イオン交換膜法によって海水濃縮を行ならさいに，水分解》あ るいは過度の脱塩さによって，膜面なとに宸酸かルシウムスケー ルが生ずる場合があり，䉓流および液流動の障害となるほか，膜 破壊などのトラブルの原因となる。これら炭酸カルシウムスケー ル（本埌に括いては炭酸カルシウムスケールのみを取り报うの で, 以下単に「スケール」といら) は, ほとえと例外なくアラゴ ナイトからなることはすでに指摘されているがす，その理由につ いては検討が行なわれていない。

著者はさきKスケールの析出条件について，海水利用率との関 係を検討し，本分解が発生しなくてるスヶールが生ずる場合があ

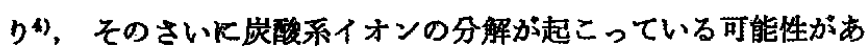
ることを指摘したが2)，それらの場合にす析出するスケールは， アラゴナイトからなることを確認したか。本報ではとれらの結果 に基づき，イオン交换膜法におけるスケール結晶の形状と変態と に対する，海水中の共存イオンの影響について倹討した結果を報 告する。

岸酸カルシウムの同質多像形飞は六方晶形のカルサイト，斜方 晶形のアラゴナイト怙よび六方晶形のバデライトの三変熊がよく 知られている。それらの生成条件についての研究は古くから行な われ(2)7, 共存イオンの影響, 温度の影響, 反応溶液濃度の影響 などについての検討が行なわれる゙ 18)，これらを反応速度でまとめ

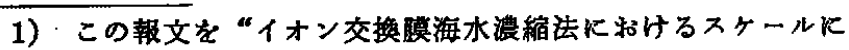
関する研究(第 6 報)”とする。

2）前報(第 5 報)，武本長昭，海水誌，26，32(1972).

* 日本専売公社中央研究所, 東京都品川区西品川

3）世古真臣, 電化, 33, 838(1965).

4) 武本長昭, 海水誌, 26, 26(1972).

5）山根礼一，水谷幸雄，市川 陸，佐田俊勝，日塩誌，18， $77(1964)$.

6) J. W. Mellor, “A Comprehensive Treatise on Inorganic and Theoretical Chemistry", Longmans Green and Co., (1925) Vol.3, p. 814.

\section{る考察るなされている14)。}

海水系から析出する炭酸カルシウムについてす，アラゴナイト が析出する場合が多いこと性古くから指摘され备，その理由につ いて種々の㭘討がなされ(11)1916)，海水中纪共存するマグネシウム の影㬜飞よるとする説があるが，いまだ不明確な部分す多い。

イオン交換膜法に和けるスタールの生成条件においては，温度 は通常 $15 \sim 45^{\circ} \mathrm{C}$ 程度の籁囲であり, 反応時の㶇度条件す通常溶 液淈合の場合ほと大幅に変化することはないと考えられるので， 本報で柱として共存イオンの影響について検討した。

\section{2 実験}

\section{1 析出スケールの定性的観案}

海水浱縮に抹けるスケール析出のさいに比較的多量飞共存する イオンとしては, 多量の塩化ナトリウムのほかに, マグネシウ ム,カリウム，硫酸の各イオンがある。そこでまずこれらの影響 を娭討するために，海水あるい㥩に述べる調製液を，図 1 の装 置を用いて濃縮してスケールを析出させ，析出スケールをX線回 折炕よって定珄的に分析するほか，その形状の湿徽鏡観察を行な った。

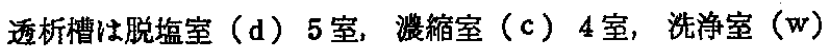

7) J. L. Wray, F. Daniels, J. Amer. Chem. Soc., 79, 2031 (1957).

8) Y. Kitano, Bull.Chem. Soc. Jap., 35, 1973(1962).

9) Y. Kitano, ibid., 35, 1980(1962).

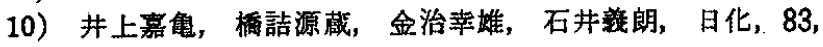
$777(1962)$.

11) Y. Kitano, D. W. Hood, J. Oceanogr. Soc. Jap., 18, 141 (1962).

12) K. Simkiss, Nature, 201, 492(1964).

13) O. Flint, M. N. Elliot, Desalination, 5, 5(1968).

14) 北野康, 工化, 59, 1346(1956).

15) H. Gee, E. G. Moberg, D. M. Greenberg, R. Revelle, Bull. Scripps Inst. Oceanogr. Tech., 3, 188(1932).

16）石坂跛一，和田吉郎，東工試報，53，409(1958). 
Table 1 Composition of feed solutions

Exp. Concentration of ions (N)

\begin{tabular}{|c|c|c|c|c|c|c|c|c|}
\hline No. & $\mathrm{Na}$ & $\mathbf{K}$ & $\mathbf{M g}$ & $\mathrm{Ca}$ & $\mathrm{Cl}$ & $\mathrm{SO}_{4}$ & $\begin{array}{l}\mathrm{HCO}_{3}{ }^{a)} \\
\left(\times 10^{-9}\right)\end{array}$ & pH \\
\hline 1 & 0.465 & 0.010 & 0.105 & 0.021 & 0.545 & 0.055 & 1.7 & 7.73 \\
\hline 2 & 0.504 & - & - & 0.019 & 0.523 & - & 1.5 & 7.67 \\
\hline 3 & 0.573 & - & - & 0.019 & 0.592 & - & 2.0 & 7. 71 \\
\hline 4 & 0.529 & - & - & 0.020 & 0.549 & - & 1.8 & 7.83 \\
\hline 5 & 0.510 & - & - & 0.019 & 0.529 & - & 2.0 & 8. 03 \\
\hline 6 & 0.482 & - & 0.107 & 0.020 & 0.609 & - & 2.2 & 8. 10 \\
\hline 7 & 0.528 & - & 0.011 & 0.022 & $0.560^{\circ}$ & - & 1.9 & 8.25 \\
\hline 8 & 0.510 & - & 0.002 & 0.020 & 0.532 & - & 1.8 & 7. 42 \\
\hline 9 & 0.559 & 0.011 & - & 0.024 & 0.539 & 0.054 & 2.0 & 7. 74 \\
\hline 10 & 0.546 & 0.009 & - & 0.018 & 0.528 & 0.045 & 2.1 & 7.77 \\
\hline 11 & 0.551 & 0.008 & - & 0.019 & 0.578 & - & 2.0 & 8. 33 \\
\hline 12 & 0.583 & 0.003 & - & 0.019 & 0.605 & - & 2.0 & 7. 72 \\
\hline 13 & 0.596 & - & - & 0.022 . & 0.568 & 0.050 & 2.2 & 7.80 \\
\hline
\end{tabular}

a) $\mathrm{CO}_{2}+\mathrm{HCO}_{3}{ }^{-}+\mathrm{CO}_{3}{ }^{2-}$ was shown as $\mathrm{HCO}_{3}-$.

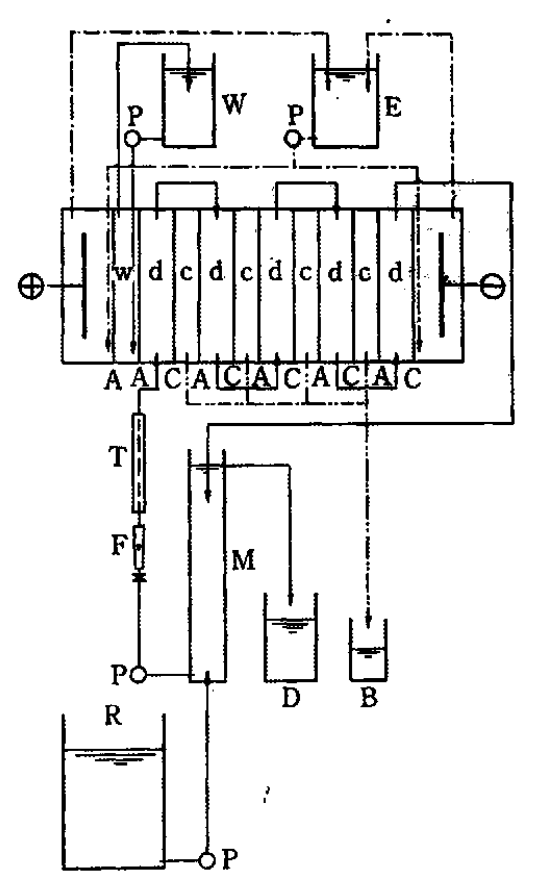

Fig. 1 Electrodialysis apparatus

C : Cation exchange membrane

A : Anion exchange membrane

c : Concentrating compartment

d : Desalting compartment

$w$ : Washing compartment

$\mathrm{R}$ : Feed solution

$\mathrm{D}$ : Desalted solution

B : Concentrated solution

W: Washing rinse

E : Solution for electrode compartment

$\mathrm{M}$ : Mixing part of desalted solution system

$\mathrm{T}$ : Temperature regulator

F : Flow meter

$P$ : Pump

1 室扰よび陰陽雨電極室からなる 12 室構成（ 5 ユニットセル） で, 有效謨面は $3 \mathrm{~cm} \times 3 \mathrm{~cm}$ である。脱塩室には, 出口温度を所 定の一定温度とするように, 温度調節器（T）で加温または冷却

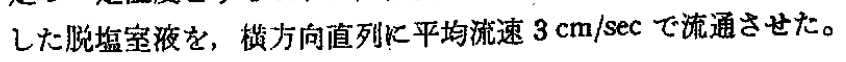

またこの脱塩液系には，湝合部（M）出口付近に原液を供給し， 夜量の増量分を混合部入口付近から溢流排出させた。溲縮室には 最初に原液を满たしたのちは液の流通は行なわず，濃樎にとるな う液量の増加分を，溢流によって排出させた。

電極には長時間連続通電を行ならため白金板を用い，電解によ って生ずる塩素かよびアルカリの影整を防ぐために，酢酸酸性の チオ硫酸ナトリウム溶液（理酸酸ナトリウムを添加して，酸性下 でのイオウの析出を防止する）を，両極室に並列に流通させた。 電極室は溜綰室型としたため，䉓極液成分が脱塩液系に混入する 可能性は少ないが，アニオン膜を通しての水素イオンの透遇性 は，他のイオンの場合にくらべてかなり大きいため，陽檽室から 脱塩液系に水素イオンが浔入する可能性があるので，陽極室に臨 接して洗浄室を設け, アルカリ性とした塩化ナトリウム淮を流 通させた。洗浄室はアニオン膜のみの構成としたが，これは脱塩 液系に対して濃縮空型の膜配置とするととるに，あわせて晹㮛室 から洗浄室への電極液成分の移行を防止するためである。

イオン交换膜にはカチオン瞙 (C)，アニオン瞙（A）飞す， 2 価イオン難透過処理を行なったスチレンージビニルベンゼン系均 質膜を使用し, 電流密度は $40 \mathrm{~mA} / \mathrm{cm}^{2}$ で一定とした。脱程率 は，原液の脱塩液系への供給量によって定まるが，これをスケ一 ルは析出してる水分解は発生しない，50〜80\%の範囲となるよ らに調整した。このような条件下ではスケールの析出量はわずか であるため，析出スケール結晶の形状および変態を定性的に検討 するための試料を採取するにる，100 時間程度連続して浱緶を行 なら必要があった。

透析原液には，表 1 に示したよらに海水（小田原海岸, 砂口 過）和よび調製液を用いた。調制液は海水とほぼ同濃度のカルシ ウムおよび炭酸水素イオンを含む塩化ナトリウム溶液, およびそ れにマネグシウム，カリウム，硫酸の各イオンを添加し，合計漠

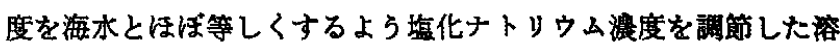
液を，特級試薬をイオン交換純水に溶解して調製した。

脱塩液および濃縮液の組成は，上記のようにいずれる澄流によ って排出されたるのを，経時的に採取分析して求めた。分析法と

17）塩化物イオンの供給量に対する脱塩液系にむける排除量の 比率で亦した. 
Table 2 Composition of concentrated solution and modification of calcium carbonate scale crystal

Exp. Temp. Concentration of ions $(\mathrm{N})$

\begin{tabular}{|c|c|c|c|c|c|c|c|c|c|c|c|c|}
\hline \multirow{2}{*}{$\begin{array}{l}\text { Exp. } \\
\text { No. }\end{array}$} & \multirow{2}{*}{$\begin{array}{l}\text { Temp. } \\
\left({ }^{\circ} \mathrm{C}\right)\end{array}$} & \multicolumn{7}{|c|}{ Hon or lons $(t$} & \multirow[b]{2}{*}{$\mathrm{pH}$} & \multicolumn{3}{|c|}{ Modification $^{0\}}$} \\
\hline & & $\mathrm{Na}$ & $\mathrm{K}$ & $\mathrm{Mg}$ & $\mathrm{Ca}$ & $\mathrm{Cl}$ & $\mathrm{SO}_{4}$ & $\begin{array}{r}\left.\mathrm{HCO}_{3}{ }^{a}\right) \\
\left(\times 10^{-3}\right) \\
\end{array}$ & & CAL & ARA & VAT \\
\hline 1 & 30 & 2. 770 & 0.072 & 0.356 & 0.101 & 3. 282 & 0.017 & 4. 8 & 7.32 & - & $H$ & - \\
\hline 2 & 30 & 2.826 & - & - & 0.103 & 2. 930 & - & 3.4 & 7.03 & $H$ & \pm & - \\
\hline 3 & 30 & 3.200 & - & - & 0.086 & 3. 286 & - & 2.8 & 7.15 & $H$ & \pm & - \\
\hline 4 & 45 & 2. 453 & - & - & 0.108 & 2. 561 & - & 3.0 & 7.46 & \# & - & - \\
\hline 5 & 15 & 3. 166 & - & - & 0.113 & 3. 279 & - & 5.6 & 6.99 & $H$ & \pm & - \\
\hline 6 & 30 & 2. 815 & - & 0.515 & 0.103 & 3. 433 & - & 4. 5 & 7. 63 & - & $H$ & - \\
\hline 7 & 30 & 2. 752 & - & 0.115 & 0.219 & 3. 086 & - & 2.6 & 6.48 & - & $H$ & - \\
\hline 8 & 30 & 2. 829 & - & 0.011 & 0.174 & 3. 014 & - & 3.8 & 7.03 & + & $H$ & - \\
\hline 9 & 30 & 3. 095 & 0.074 & - & 0.084 & 3. 215 & 0.038 & 6.1 & 7.39 & \pm & $H$ & - \\
\hline 10 & 30 & 3. 186 & 0.051 & - & 0.075 & 3. 221 & 0.091 & 3.9 & 7.24 & \pm & \# & - \\
\hline 11 & 30 & 3. 350 & 0.051 & - & 0.093 & 3. 494 & - & 4.7 & 7.71 & - & H & - \\
\hline 12 & 30 & 3. 361 & 0.016 & - & 0.092 & 3. 469 & - & 4.0 & 7.34 & + & $H$ & - \\
\hline 13 & 30 & 3. 235 & - & - & 0.080 & 3. 256 & 0.060 & 10.3 & 7.47 & H & \pm & - \\
\hline
\end{tabular}

b) $\mathrm{H}: 60 \%<,+: 20 \sim 40 \%, \pm: 10 \%>,-$ : unrecognizable.

しては, 塩化物イオンkは Fajans 法銀滴定, カルシウム, マグ ネシウムおよび硫酸の各イオンにはキレート滴定法, カリウムイ オンには炎光光度法, 全崖酸には Van Slyke 法を採用し,ナト リウムイオンは計算で求めた。

析出スケールの検討は，X線回折分析ならび飞顕微鏡観察によ って行なった。上記のよらに 100 時間程度の連続漕縮を行なった のち，ただちに透析槽から夜を全部排出し，解体して膜面をスケ 一ルが流失しないよらにしながら手早く水洗し，紙でできる だ脱水したのちスケールの付着している膜をそのままデシケー タ内で常温で乾嬠させた。スケールの大部分はこの条件下ではフ ニオン膜の浱縮側面析出しており ${ }^{18}$ )，この操作で乾燥試料が得 られるが，その量はわずかであるので，七ロハン粘着テープをス ケールが析出している膜面に押しつけることによって，5 $\mathrm{mmX}$ $15 \mathrm{~mm}$ 程度の面にスケールを捕集し，これをX線回折分析扣よ び影徽鏡観察の試料とした。なお X線回折分析火は，主として理 学電機製ガイガーフレックス 2001 型装置を, また顕徽鏡滰は才 リンパス POS 偏光顯徽鏡を用いた。

\section{2 アラコナナイトの生成条件}

後に述べるよらに，カリウムイオンの共存によってアラゴナイ トが生成することがわかったので，カリウム共存下K利けるアラ ゴナイトの生成量を，定量的に检討した。

透析装置は前項と同じく図1のものを用い, 前項と同じ条件, 括 よび原液中の炭酸水菜イオン濃度を $4 \sim 6 \times 10^{-3} \mathrm{~N}$ とし, 脱塩率 を 85〜90\% とすることにより，スケールの析出速度を増大させ た実験を行なった。透析終了後濃縮室に析出したスケールを，全 量分離採取し, 水, アルコール, エーテルで順次洗浄し風乾した。 スケールの組成の分析は，水酸化アルミニウムを内部標準と し，水酸化アルミニウム，カルサイト，アラゴナイトおよびバテ シイトの，それぞれ $d=4.7,3.035,3.396,3.58 \AA$ 飞拈けるX 線回折强度を用いて行なった。前に述べたようにスケールの析出 量はわずかであったので, 塩化ナトリウムを添加して堌量すると ともに, 陚料容器をできるだけ小さくして分析を行なった。内部 標準に水酸化アルミニウムを採用したのは, 回析線の位置関係な とが，通常用いられているシリカよりる適当であると判断したた

18）武本長昭，海水誌，21，235(1968).
めであり，塩化ナトリウムによって増量したのは，試料スケール 中に，処理の過程で塩化ナトリウムが析出混入する可能性が大き く，また塩化ナトリウムによるX線の回折するいは吸収が，分析 の妨害にならないことを確かめたためである。なおカルけイト， アラゴナイト怙よびバテライトの試料は，塩化カルシウムと炭酸 ナトリウムの溶夜を，井上らの検討結果 ${ }^{10)}$ 飞る基づいて種々の条 件で混合することによって調製し、X線回折によって確認したも のを使用した。

\section{3 結果と考察}

\section{1 共存イオンとスケール結晶の変龍}

定性的検討(2.1)の結果を, まぬて表 2 に示した。液組成とし ては、スケールの生成母夜である濃縮液の組成走示した。X線回 折分析の結果恃, 分析試料の調製方法が回折角战よび強度を定量 的に报らものとしては不適当であると考之たため, 四 2 に示した 各試料の X線回折図を, 各変態試料を種々の割合で混合して調製 した標準試料についてのX線回折四と比較することにより，打拈 まかな組成範囲を推定して記号で示した。な和图2 亿あわせ示し てあるカルサイト，アラゴナイト括よびバテライトのX線回折図 は，2.2で述べたよらにして調製したもの炕ついて，通常の粉末法 の操作によって测定したるのであり，これらはいずれるASTM(19) の数值とよく一致している。また上記の組成範囲の定性的な推定 には，後に述べる顕微鏡観察の結果も加味した。

表 2 の結果から見て，海水の場合（実験 No.1）飞は汪ばアラ ゴナイトだけが析出することを確認し，塩化ナトリウム溶夜中で は主としてカルサイトが析出し (No. 2, 3)，温度が低い場合(No. 5）よりも温度が比較的高い場合の方が，ほとんどカルサイト なることがわかった（No.4）。

従来より，海水から析出する炭酸カルシウムが，アラゴナイト になる場合の理由として，一致して举げられていたマグネシウム イオンKついては, 海水と同程度共存する原液を濃縮した場合に は、ほとんどアラゴナイトとなり (No.6)，マグネシウムイオン の共存量が少なくなるにしたがって，しだいルカサイトが多く

19) A.S.T.M., “X-Ray Diffraction Data”, 5-0453, 5-0586, 13-192. 


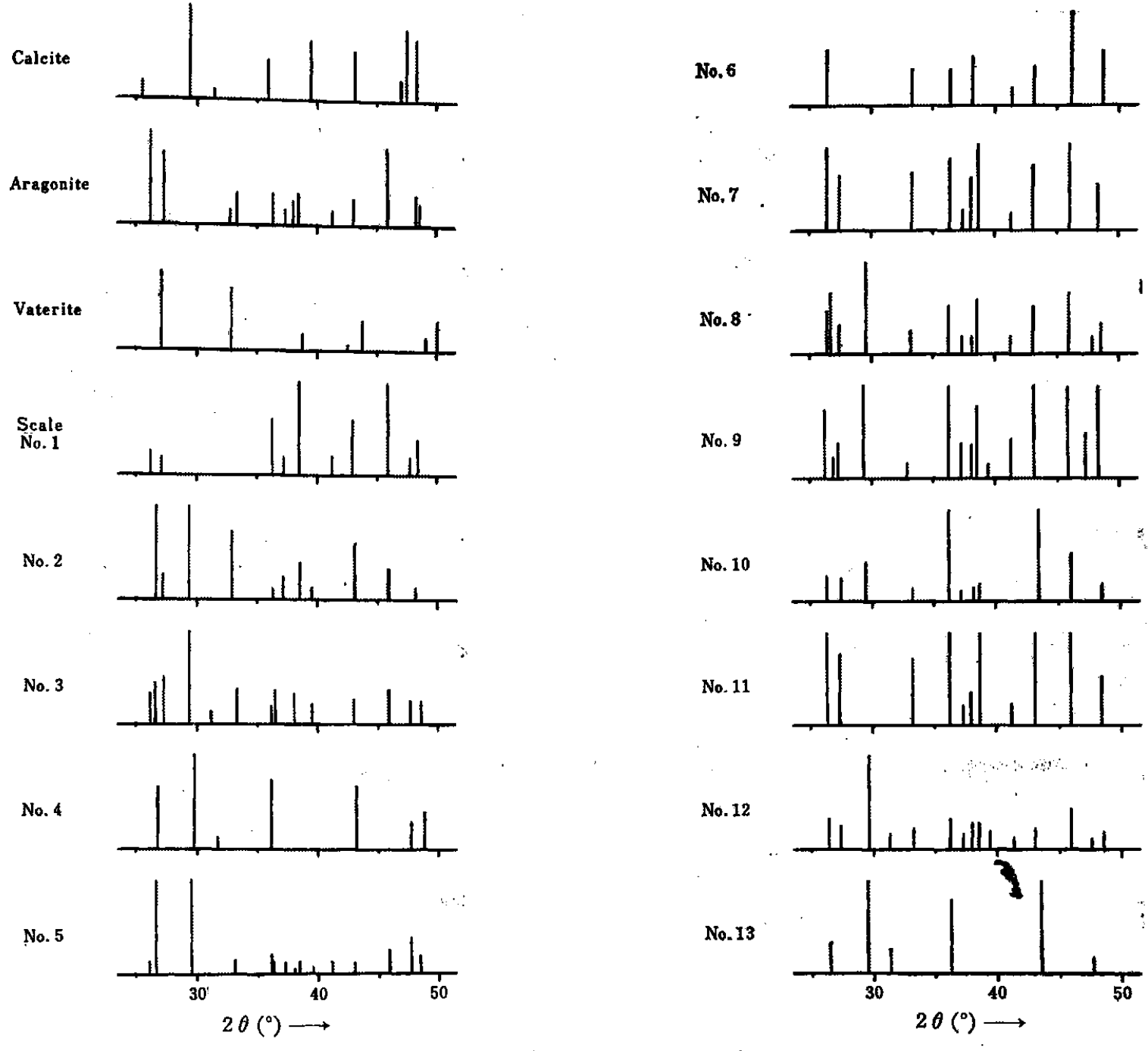

Fig. 2 X-ray diffraction patternş of scales

混在するようになることを確認した（No.7，8)。

アラゴナイト生成に対するマグネシウムイオンの影蠁は，この ようにして確認できたが，海水からマグネシウムイオンを除いた 組成についてもアラゴナイトの析出が認められた (No.9，10)。 そこで，カリウムイオンと硫酸イオンの影響について検討したと ころ，カリウムイオンの共存によってアラゴナイトが生成し，そ の共存量が減少すれば，カルサイトの混在量が增すことが明らか Kなった (No.11，12）。一方, 硫酸イオンについては, 少なくと る海水程度共存する原液を浱縮した場合には，アラゴナイトは生 成せず，カルサイトのみが生成した (No. 13)。

従来アラゴナイト生成関与する共存イオンのらら, 海水中に 比校的多量飞存在するイオンとしては，さきに述べたマグネシウ ムイオンのほかに, ナトリウム, カリウム, 硫酸, 塩素なとの各 イオンがあげられているき。しかしこれらのイオンのらちで，海 水からアラゴナイトが生成する原因になるイオンとして確認され ているものはマグネシウムイオンのみであり，マグネシウムを含 有しない海水からはカルサイトとバテライトを生ずると報告され ている12)。

これらに対し上記の実験の結果を総合すると、イオン交換膜法 スケールははぼ純粘なアラゴナイトであり，その生成原因の一つ にマグネシウムイオンの共存が挙げられることは，従来の知見と
同しであるが，共存するカリウムイオンるアラブナイト生成の原 因の一つであり，ナトリウム，硫酸および塩素の各イオンは，フ ラゴナイトの生成に汪とんど関与しないことが明らかになった。 カリウムイオンの影響と, 従来の知見との相遑に関する検討につ いて绀, 3.3 で述べる。

\section{2 スケール結晶の形状}

つぎに上記の各種策件下で析出したスケールの顕制鏡写真を, 因3に示した。各写真の No. は, 実験 No. と対応している。

海水滑縮のさい反生成するスケール (No.1) は，海水と同程度 Kマグネシウムイオンが共存する場合 (No.6) と同 じ棈円形を なし，やはりマグネシウムイオンの影響が支配的であることが明 らかである。

これらに対し，マグネシウムイオンの共存量を減少させた場合 (No. 7, 8)，およびカリウムが共存する場合（No.11，12）火生成 するスケール中のアラゴナイトは，細長い柱状の結晶であり，海 水濃縮の場合とはようすがかなり異なる。海水中のカリウムイオ ンは，マグネシウムイオンにくらべて共存量が $1 / 10$ 程度である ので,カリウムイオンの共存量を 10 倍程度に增加させた実験る 行なって見たが，析出したスケールの形状は四 3 No. 11 とまっ たく同様であった。

マグネシウム呿よびカリウムイオンの共存量が少なくなると， 


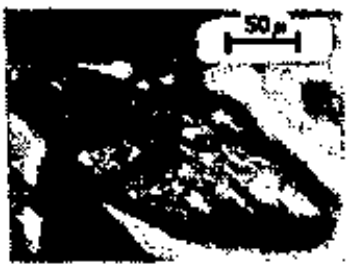

No. 1

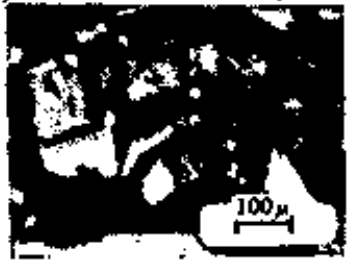

Nia. 2

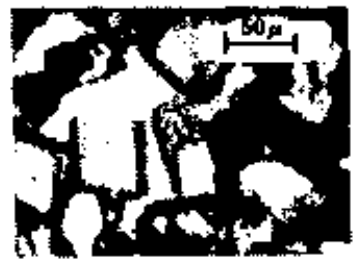

N.. 3

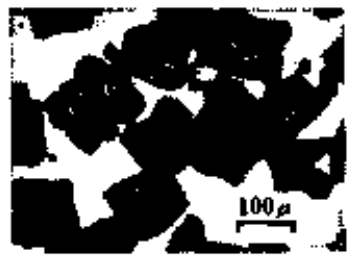

No. 4

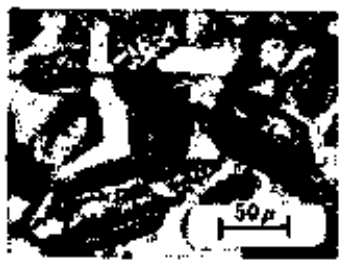

No. 9

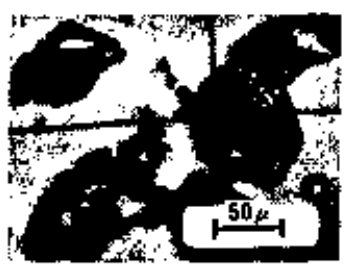

No. 10

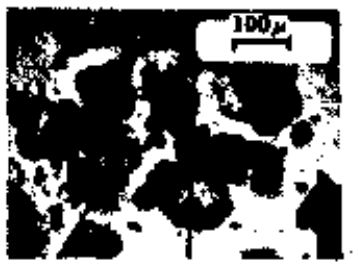

No. 5

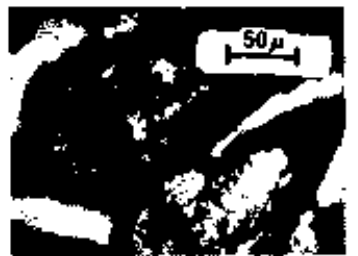

H. 6

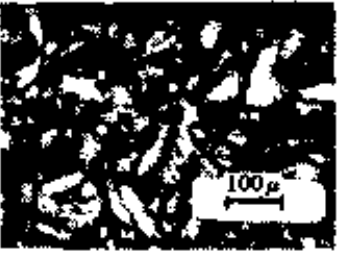

No, 7

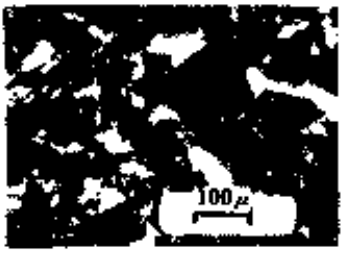

No. 8

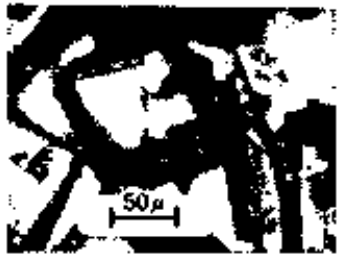

No. 12

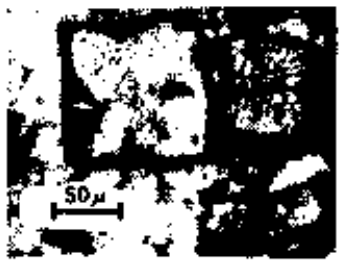

No. 13

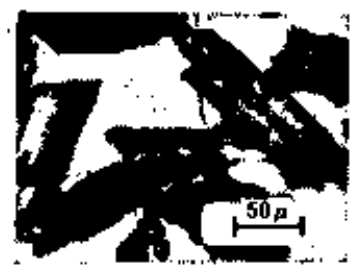

No. 11

Fig. 3 Configurations of scales

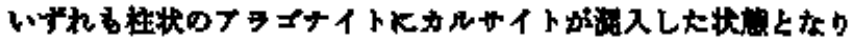

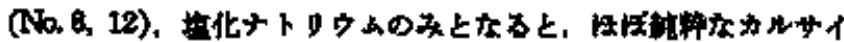

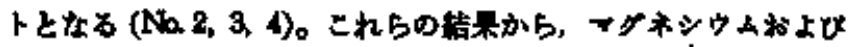

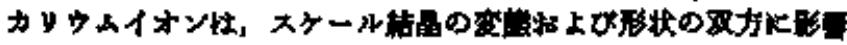

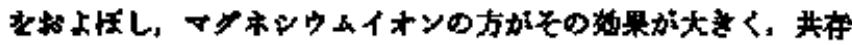

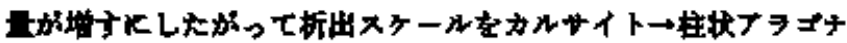

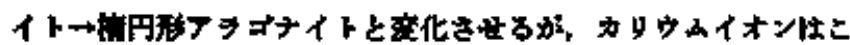

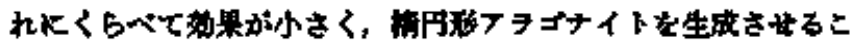

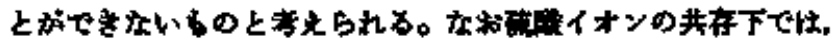

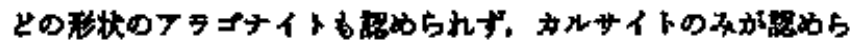
机た (Na 13)。

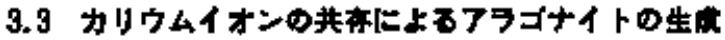

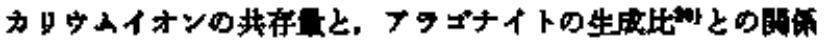

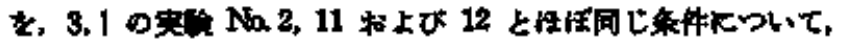

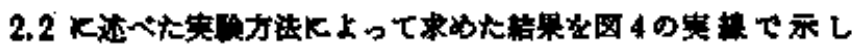

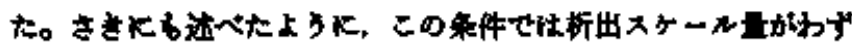

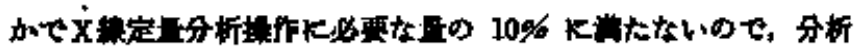

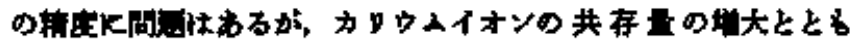

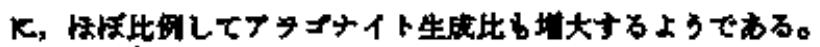

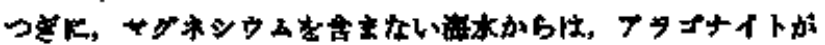

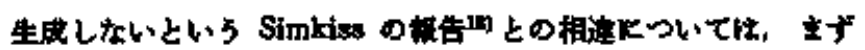

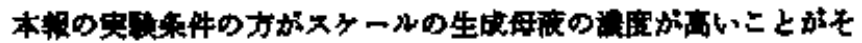

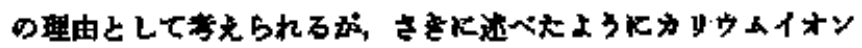

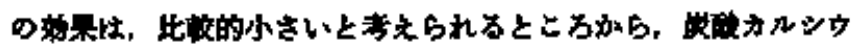

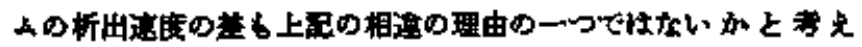

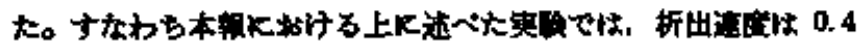

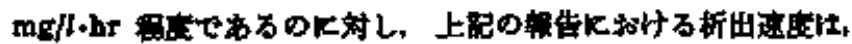

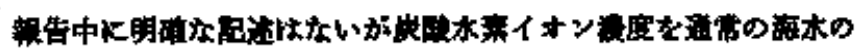

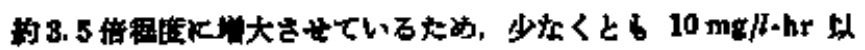
上飞䢖しているいのと推定される。

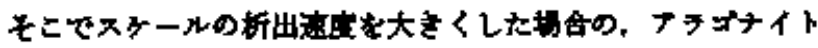

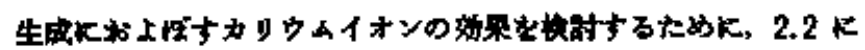

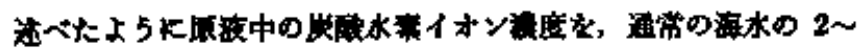

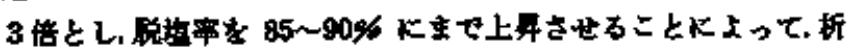

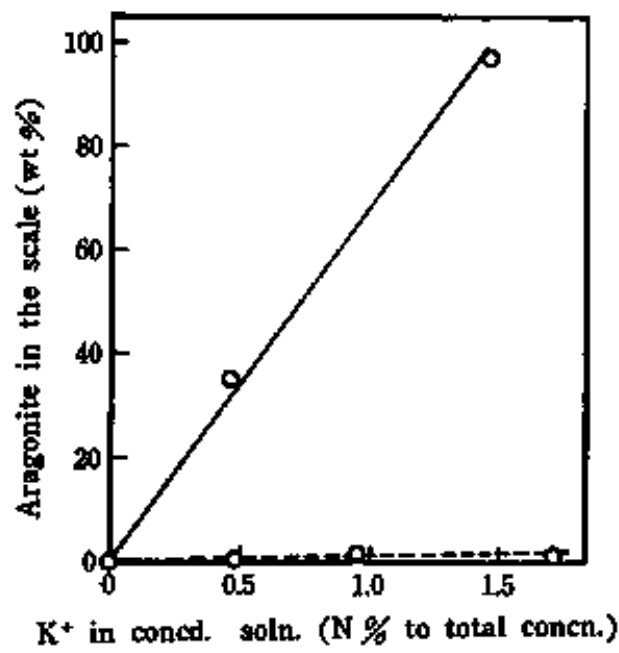

Fig. 4 Aragonite formation by $\mathrm{K}^{+}$ Rate of the scale formation ( $\mathrm{mc} / \mathrm{h} \cdot \mathrm{hr}$ ) $-\mathrm{O}-: 0.4,--\mathrm{O}--: 2$

20) 析出メケール中のフラジイトの善量比. 
出速度を約 $2 \mathrm{mg} / l \cdot \mathrm{hr}$ 程度まで增大させた実験を行なった。その 結果, この析出速度は上記の報告沉ついての推定值よりすはるか に小さいKすかかからず，析出スケール中には园4の点線で示し たよらKアラゴナイトはほとんど㸾められなかった。この結果 は、アラゴナイトの生成好対するカリウムイオンの协果は小さい ために，炭酸カルシウムの析出速度が非常飞小さい場合にのみそ の効果が認められることを示す。

イオン交換谟で海水を灌縮する場合のスケールの析出速度は, 办分解などの異常な状熊を䟻き，小わゆる部分的な過帨暒による 場合には，析出の部位，状況および析出スケール量から判断し て，本報の実験に斿ける $0.4 \mathrm{mg} / \mathrm{l} \cdot \mathrm{hr}$ 程度かあるいはそれ以下 であると教られる。すなわちこれはカりウムイオンの共存によ ってアラジナイトが生成する範围である。

イオン交換膜の製造方法および処理方法などの改善によって, 漕縮された海水中の 2 便イオンの共存量は今後ますます減少する 縩慜にある。この場合カルシウムイオンよりもマグネシウムイオ ンの方がより減少の程度が大きく，一方，カリウムイオンの共存 量はむしろ增大の傾向がある21。したがって少なくとる部分的過 21）珷本展炤，海水誌，24，213(1971).
脱塩の結果析出ナるスケールは，棈円形のアラゴナイトから柱状 のアラゴナイトに変化するすのと予想される。

\section{4 結 語}

以上に述べたように，イオン交換膜法によって海水灌縮を行な う場合火，生成する炭酸カルシウムスケールはフラゴナイトから なり、これは主として共存するマグネシウムイオンの影䈏による るのであることを確瑟した。また同しく海水中K共存するカリウ ムイオンKよってる，アラゴナイトが生成することる明らか炕 し,ナトリウム்イオンと硫酸イオンは、はとんどアラゴナイト生 成に関与しないことを明らかにした。

冒頭にも述へたように，イオン交換膜法に和けるこれらのス々 一ルによるもっとも大きなトラブルは膜破垻であり、析出スケー ルの結晶形と膜への影響との間火は，直接あるい間接関係が ある上らに考えられるので，今後検討を行ないたいと考えている。

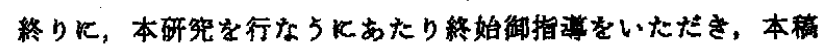

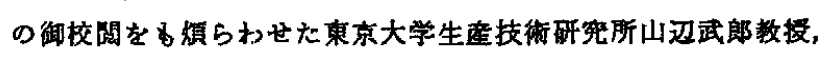
ならび日本專売公社中央研然所渡部忠行第八部長に，㳭甚なる 謝意を表します。

\title{
Configuration and Modification of Calcium Carbonate Scale Crystals Deposited on Ion Exchange Membranes ${ }^{\dagger}$
}

\author{
Nagaaki TAKEMOTO
}

The Central Research Institute, Japan Monopoly Gorporation; Nishishinagawa, Shinagawa-ku, Tokyo, Japan

In concentrating sea water by the electrodialysis using ion exchange membrane, modification of calcium carbonate scale crystal, formed by either water decomposition or over-desalination, has already been known to be aragonite. In this report, the author studied the contribution of ions in sea water to the aragonite formation.

To the sodium chloride solution containing calcium and bicarbonate ions, magnesium, potassium and sulfate jons were added and the solution containing the same concentration as sea water was prepared. The concentrating experiment of this solution was carried out for about $100 \mathrm{hr}$ by the use of the electrodialysis apparatus consisting of five unit cells of ion exchange membranes with $9 \mathrm{~cm}^{2}$ in effective area. $50 \sim 90 \%$ of chloride ion was introduced into the concentrated solution to realize over-desalination without accompanying water decomposition.

On the basis of the $\mathrm{X}$-ray diffraction analysis and microscopic observation on the calcium carbonate scale deposited, the following conclusions were obtained.

(1) When sodium, chloride and sulfate ions coexisted, the scale formed was not axagonite but calcite (No. 2, 3, 4, 5 and 13 in 'Table 2, Fig. 2 and Fig. 3).

(2) When magnesium ion coexisted, aragonite of elliptical configuration, as in the case on sea water, was formed. This seemed to show dominating contribution of the ion to both modification and configuration of the scale crystal (No. 1 and 6).

(3) When potassium ion coexisted, aragonite of rod-like configuration was formed, which was also observed when the amount of coexistent magnesium ion became low (No. 7, 8, 11 and 12).

(4) When the scale was formed slowly, the ratio of aragonite existing in the scale to the coexistent potassium ion was nearly $1: 1$, but when the scale was formed rapidly, it was almost $0: 1$ (Fig. 4).

† Scale Formation in Concentrating Sea Water with Ion Exchange Membrane Method. VI. 